\title{
Energy efficiency in SMEs: overcoming the communication barrier
}

\author{
Jenny Palm (D) Fredrik Backman
}

Received: 27 May 2019/Accepted: 8 January 2020 /Published online: 15 January 2020

(C) The Author(s) 2020

\begin{abstract}
This article discusses ineffective knowledge and information communication as an important barrier to improving energy efficiency in small and mediumsized enterprises (SMEs) and considers how to make functional communication an enabler of future SME energy-efficiency programmes. Energy audits - important tools when addressing energy efficiency in companies - are often performed by professionals with an engineering background, which does not reflect the backgrounds of those receiving the audit, inhibiting the interpretation of those audits. SMEs must actively process the information, and their employees must be able to connect the information to existing knowledge.

We analysed two methods used by Swedish municipal energy-efficiency programmes to improve energy efficiency in SMEs. The results indicate that in the programme providing SMEs with third-party information, but without any possibility to process the information, the energy-efficiency results were poor, while in the programme in which SMEs were actively engaged in all stages and could discuss problems and results with peers, the energy-efficiency results were better.
\end{abstract}

J. Palm $(\bowtie)$

Lund University, International Institute for Industrial

Environmental Economics, 22100 LUND, Sweden

e-mail: Jenny.palm@iiiee.lu.se

F. Backman

TEMATechnology and Social Change, Linköping University, 581

83 Linköping, Sweden

e-mail: Fredrik.backman@energimyndigheten.se
In implementing SME energy-efficiency programmes, municipalities should avoid simply offering audits. Instead, they should find methods that facilitate knowledge creation among the participants, allowing the participating SMEs to share experience and knowledge with one another and with experts, and to take home ideas, testing them in their own contexts, and communicating their experiences. This would be a way to make communication an enabler rather than a barrier.

Keywords Communication - Knowledge creation . Energy-efficiency programme $\cdot \mathrm{SME} \cdot$ Barriers

\section{Introduction}

For the global energy system to implement the Paris Agreement and keep global warming below $2{ }^{\circ} \mathrm{C}$, energy efficiency will have to be one of several important means by which industry reduces its environmental impact (IEA 2019). Several studies of small and medium-sized enterprises (SMEs) have found that despite the existence of cost-effective energy-efficiency measures, implementation of energy-efficiency investments is often low (Rohdin et al. 2007; Trianni et al. 2016; Backlund et al. 2012). According to research, this low implementation is due to the existence of various barriers to energy efficiency (see, e.g. Cagno et al. 2013; Decanio 1998; Engelken et al. 2016; Sorrell 2004; Thollander et al. 2010; Trianni and Cagno 2012). In this context, a barrier is defined as a factor that prevents or discourages a decision or behaviour that appears to be 
both energy efficient and cost-effective (Sorrell 2004). Most measures outlined in research and policymaking are dominated by the techno-economic perspective (Labanca and Bertoldi 2018). The dominant policy means discussed for supporting energy efficiency are energy audits, energy-audit programmes, and in-house energy management. Here, we will discuss ineffective communication as an important barrier to improving energy efficiency in SMEs and how to make functional communication an enabler of future SME energyefficiency programmes (compare Hampton 2019). In this article, communication refers to the imparting or exchange of information or knowledge concerning energy efficiency, and the EU Commission's definition of an SME is used, i.e. an SME is an enterprise with fewer than 250 employees, an annual turnover not exceeding EUR 50 million and/or an annual balance sheet total not exceeding EUR 43 million.

The management of energy efficiency in industry has traditionally assumed that governments should only intervene in markets when so-called market failures arise (Palm and Thollander 2020). Regarding energy efficiency, two market failures are in the forefront, information asymmetries, and information imperfections. Lack of information (Sanstad and Howarth 1994) and cost of information means that costs are associated with seeking and acquiring information about energy-efficient solutions (Sorrell 2004), both exemplifying information imperfections. An example of information asymmetry is adverse selection: for example, when a supplier knows more about the energy performance of items than does the purchaser, the purchaser may select an item only in relation to other premises such as price (Jaffe and Stavins 1994). Common policy recommendations to overcome these barriers are (1) energy-efficiency programmes, including identification of opportunities for technology improvement, generally through energy audits or other technical assistance and (2) direct financing or other facilitation of identified opportunities (Thollander et al. 2010). However, not only is lack of information and knowledge a barrier but also how this information is communicated (Hampton 2019), a matter that will be studied here. We will discuss two programmes targeting SMEs in Sweden, analysing them in relation to how information and knowledge are communicated within these programmes.
A key aspect of all energy programmes is to establish energy management systems and/or strategies in companies (Abdelaziz et al. 2011). Energy management includes the planning of energy-efficiency investments and the care and maintenance of current technology to maintain energy-efficient operations (Gordić et al. 2010). An energy audit is a typical first step when initiating energy-management activities or related policy programmes (Thollander and Palm 2013).

Earlier research has noted that a technical approach is often used when conducting straight forward energy audit programmes (EAPs) and that this approach often leads to energy management being overlooked. This type of analysis hides the influence of SME staff on the technology and the decision-making process (Palm 2009). Change is therefore required in how energy-efficiency programmes are designed (Thollander and Palm 2013). Another problem is that such energy audits are often performed by professionals with a background in engineering (Fleiter et al. 2011) and then given to SMEs that may lack similar background knowledge, making it difficult for the SMEs to interpret the audit results.

This kind of linear model - in which external information enters, information is processed mechanistically, and then SMEs make decisions or investments to improve their energy efficiency - often yields disappointing results. Although general informational campaigns such as energy audits result in increased awareness of energy-efficiency potential in SMEs, such campaigns rarely seem to result in large increases in the adoption of energy-efficiency measures; they must be complemented with training programmes or other practical measures to yield good results (Väisänen et al. 2002). Earlier research has discussed information deficiencies as a major barrier to improved energy efficiency in SMEs (Golove and Eto 1996), as well as a lack of training to process complicated and unfamiliar data (Henriques and Catarino 2016). Local energy programmes starting with the actual needs of SMEs are said to be more successful than a generalized model approaching all companies in similar ways (Thollander and Palm 2015). Government-funded energy programmes can take a broader view by including educational workshops and training programmes for SMEs (Anderson and Newell 2004). The use of a peer group has proven successful 
in earlier models, such as Energy Model Zurich, used since 1986 in Switzerland, Model Hohenlohe in Germany, and Ökoprofit, used since 1993 in Austria. Peer groups have also successfully been used by UNIDO and RECP clubs, both of which emphasize energy efficiency (see, e.g. Ceglie and Dini 1999; Urbaniec and Gerstlberger 2011; Durand et al. 2018).

An SME must actively process information internally, and its employees must be able to control their own learning processes by selecting and organizing relevant information and building connections to existing knowledge (Thollander and Palm 2015). Therefore, a primary goal of policy programmes should be to help SMEs develop their learning skills and then help them use these skills to construct useful knowledge in relevant areas (Mayer 1992).

Earlier research emphasized information and knowledge transfer, paying less attention to the fact that SMEs do not automatically translate information into useful knowledge. This paper will address this research gap by discussing SME energy-efficiency programmes from the perspective of communication, which entails the active involvement by two parties, for example, in an energy audit. Priority will be given to engaging and involving the SMEs and treating SME perspectives and problems as a starting point. The article will analyse two energy-efficiency programmes run by two Swedish municipalities to improve energy efficiency in SMEs, comparing the methods used and how energy-efficiency information was communicated. First, we will present an overview of earlier research on knowledge and information.

\section{Communication of knowledge and information}

An energy audit is a typical first step when initiating energy management practices or related energy programmes. Energy audits have traditionally applied a technical approach, being performed by professionals with a background in engineering (Fleiter et al. 2011). In general, the energy audit is an investigation of the energy used by a company's support and production processes. The results of an energy audit often take the form of a report containing various types of data provided by external sources. The idea is that information and knowledge from the audit is transferred to the receiver, who will then take action in relation to the outcome of the audit (Palm and Thollander 2020).
In this audit process, information and knowledge are central concepts. Here, knowledge will be treated as more than simply gathered and disseminated information. Davenport and Prusak's (1998) definition of knowledge is used:

Knowledge is a fluid mix of framed experience, values, contextual information, and expert insight that provides a framework for evaluating and incorporating new experiences and information. It originates and is applied in the minds of knowers.

Knowledge is thus not seen as "flowing" unchanged between sender and receiver. Rather, social interaction in the form of dialogue between actors is needed, through which implicit and tacit knowledge can be negotiated, interpreted, and integrated (Noorderhaven and Harzing 2009).

Both Nonaka and Takeuchi (1995) and Polanyi (1983) argued that knowledge should be seen as consisting of two parts: explicit knowledge and tacit knowledge. Explicit knowledge, also known as information, is often expressed or codified in reports or documents in a formal manner using words and numbers and can easily be diffused between actors (Terzieva 2014), for example, between energy experts and SMEs. Tacit knowledge, on the other hand, involves skills and know-how applicable to specific work, along with unarticulated mental models and understandings that have been internalized and cannot be written down; therefore, this kind of knowledge has a practical or learn-by-doing dimension (Ikujirō Nonaka and Takeuchi 1995; I. Nonaka and von Krogh 2009). Tacit knowledge cannot be learned through demonstration or instruction alone (Lave and Wenger 1991). Personal experience, practice and imitation, storytelling, and the sharing of best practices and lessons learned are often required (Terzieva 2014). Tacit and explicit knowledge are not independent of each other but are mutually complementary. They dynamically interact with each other when individuals and groups engage in creative activities through social interaction (Ikujiro Nonaka 1994; Polanyi 1983). Therefore, learning is rooted in activity and interaction, especially when people attempt to solve problems from an organizational perspective (Arrow 1971).

Knowledge possessed by individuals must be passed along to others for its value to be leveraged. Knowledge flows include the creation, transfer, and integration of distributed knowledge (Cabrera and Cabrera 2005). External partners, such as consultants, can also be an excellent source of new knowledge (Matusik and 
Charles 1998) providing that they manage to communicate assumptions, calculations, and results properly. Light (1989) explained that communication competence is "a relative and dynamic interpersonal construct". Communication also includes the exchange of experiences, for example, by the participants in a meeting or conference call. Learners must internalize knowledge, making it their own and situating it in their particular environment (Hildreth and Kimble 2002). From this perspective, knowledge is dynamic, relational, and based on human action; it depends on the situation and people involved rather than on absolute truth or artefacts (Davenport and Prusak 1998).

This relates to the results of research applying the community of practice (COP) theory, which argues for a situated social learning experience. Lessexperienced members learn the practice of a community from its more experienced members and by being situated in it (Lave and Wenger 1991). Situated learning activities are often centred on meetings, small-group discussions, conference calls, and group searches for new knowledge topics (Probst and Borzillo 2008; Thollander and Palm 2015). In COP theory, the social context of the various activities through which learning takes place is important for the learning process (Nahapiet and Ghoshal 1998). The context and type of activity are not the only important factors when considering learning. When people learn, their environment is an integral part of their learning experience that shapes what is learned (Lave and Wenger 1991). This is because activities, tasks, functions, and understandings do not exist in isolation but are part of a broader network of relations in which meaning is created (Lave and Wenger 1991).

Participation is the process of taking part in something; it includes personal relations with others involved in the same or a similar activity. Participation involves both action and connection in a personal and social way. This process combines doing, talking, thinking, feeling, and a sense of belonging (Wenger 1998). The other key component that makes up the negotiation of meaning is reification, i.e. considering something an object or thing. Reification refers to the process of giving form to our experience by producing concrete objects, such as an energy audit report or investment plan, from an abstract concept (Wenger 1998).

Since participation and reification complement each other, another important aspect of this duality is the balance between the two. Participation and reification must occur in the right proportions for each to remain in equilibrium with the other (Wenger 1998). For example, if all input is reified but there is little opportunity for experience sharing and interactive negotiation, such as in a EAP, then there may be insufficient participation for SMEs to find relevance and generate meaning or value. This insight can help to explain why energy-efficiency programmes that only contain an informational part do not seem to increase realized energy-efficiency measures among SMEs.

Since knowledge is socially constructed, taking an artefact such as a report from an energy audit or an investment plan away from its original context creates interpretive flexibility or latitude for different local interpretations (Star and Griesemer 1989). The knowledge embedded in an artefact during its creation is not simply re-extracted in its new environment or context; rather, a degree of tacit knowledge is necessary to be able to make use of the embedded knowledge (Hildreth and Kimble 2002). Since there is a possibility that certain interpretations could distort the original meaning, it is preferable to have people and artefacts travel together during the process. Learning in this way takes advantage of the complementarity of reification and participation. Having people and artefacts travel together restores the balance between reification and participation and makes negotiation of meaning possible (Wenger 1998).

Wenger's notions of reification and participation provide a way forward for energy-efficiency programmes. The German experience with energyefficiency networks has partly integrated this perspective, and the German model has proven successful in increasing the implementation rate of energyefficiency measures, not only in SMEs but also in large companies. The idea of energy-efficiency networks emerged in Zurich, Switzerland, in 1987 and then further developed in the 1990s in Switzerland. With inspiration from Switzerland, the first German learning energy-efficiency network was founded in 2002 in the Hohenlohe region, south-east of BadenWürttemberg (Jochem and Gruber 2007). Durand et al.'s (2018) evaluation of German learning energy-efficiency networks (LEENs) shows that the energy savings achieved by 330 companies in 28 LEENs averaged $2.3 \%$ per year within 4 years. The German model will be described next. 
Knowledge creation in energy-efficiency networks

In the German model, LEEN has been used (Jochem and Gruber 2007). LEENs are arenas for interactive learning in which networks are used to enhance knowledge sharing (Chow and Chan 2008). Knowledge and information are negotiated through face-to-face interactions between actors (Pinch et al. 2003). Such networks will better support learning if they are guided by a bottom-up process through which it is possible to create and exchange knowledge and information by means of an interactive process of learning-by-doing (Köwener et al. 2011; Köwener et al. 2014).

Important factors when setting up these networks include mutual trust, access to help, mixed formal and informal groups and communities, shared structures and goals, best practices, tools, and sharing spaces. Trust between actors is considered a critical factor that affects interfirm knowledge creation and plays a key role in the willingness of network actors to share and accept knowledge (Inkpen and Tsang 2005; Lorenzen 2001). A trusting environment is not only important between the SMEs themselves but also between the SMEs, the project leader, and insourced energy experts. The results of the energy audits and the SME's perception of the trustworthiness of the suggested new solutions can greatly affect the decisions an SME will make regarding energy-efficiency measures. By using this type of network, it is possible to create an environment that better facilitates companies' capabilities for sense making, knowledge creation, and decision-making (Choo and de Alvarenga Neto 2010), since organizations such as SMEs act through network relationships with different actors that constrain, shape, and enable their actions (Biggart and Lutzenhiser 2007). In this sense, an interfirm network acts as a "social community" (Kogut and Zander 2003) that can be compared to a COP, as described above.

With this in mind, we will next describe the method used to collect the data. Then we will discuss two methods used in different energy programmes in Sweden to deal with information and communication.

\section{Method: case studies of two municipal policy programmes}

This exploratory study was conducted as a multiple case study (Patton 2015) with two cases, cases 1 and 2.
Interviews (Rubin and Rubin 2012) and document studies (Bowen 2009) were used in both cases, and data were collected from 2016 to 2018 . The two investigated samples involved local energy programmes intended to assist Swedish SMEs; the samples were selected using a theoretical sampling process commonly used in qualitative research (Coyne 1997). Theoretical sampling - a form of analytical sampling - is an appropriate way to obtain data for analysis aiming to "discover categories, properties, and interrelationships that will extend the theory" (Meredith 1998), which is in line with the purpose of this study to extend the current understanding of how information on energy efficiency is communicated to SMEs.

Document studies provided most of the empirical material in case 2. Document studies are often used in combination with other qualitative research methods to triangulate data (Patton 2015) and here were complemented with interviews. In case 2 , the examined energy programme had run for a long period, and documentation of the process and an evaluation were available from the participants and sufficient for the analysis when paired with complementary interviews. The analysed documents concerned the 2009-2016 period and consisted of policies, procedures (including performance-appraisal documents), and final reports from SMEs and the project leader.

The situation in case study 1 was the reverse, since no progress reports or final results existed and little official documentation could be found, making it necessary to conduct interviews; here, the interviews were complemented with the conducted energy audit.

During the interviews in both cases, a combination of structured and semi-structured questions was used. In the structured questions concerning 22 communication barriers, we asked the interviewee to rate the importance of each barrier on a scale ranging from 1 to 5 , where 1 meant "disagree (not important)", 3 meant neither agree nor disagree (neutral), and 5 meant "fully agree (important)". The questions on drivers were open-ended. The other open-ended questions concerned (1) the interviewee's background and role in the project; (2) information about the energy-efficiency programme, for example, its goal, what the interviewee did in the project, achievements, and the process as such; (3) what the programme provided to the involved actors; (4) why the interviewee participated in the project; (5) the energy-efficiency outcomes achieved so far; and (6) 
other comments the interviewee wanted to add. The semi-structured questions resulted in an interview resembling a conversation, and both the researchers and interviewees could elaborate on the questions and associate freely (Kvale and Brinkmann 2009; Rubin and Rubin 2012).

The interviews were audio recorded and later downloaded to a computer for analysis. The interviewees, municipalities, and SMEs were anonymized, so general terms such as "energy manager" are used when referring to interviewees.

The data for case study 1 were collected in 2016, about 1.5-2 years after the SMEs had participated in the studied project. In total, 60 local SMEs participated in the energy programme. The SMEs were first contacted by email with a short introduction to the research project, which was followed up by phone calls. Twenty-seven SMEs agreed to be interviewed over the phone. Of these, 22 answered all the questions, while 5 could only answer the first general questions, but not those specifically about the energy programme they had participated in. The interviews lasted 15-60 min.

In case study 2, the data were collected from 2016 to 2018. The SMEs interviewed had been part of the energy programme. In total, 22 SMEs had participated between 2009 and 2016. Seven semi-structured phone interviews were conducted with representatives of the SMEs involved in the projects, the project leader, and the involved energy experts. These interviews usually lasted 15-45 min. In this case, the interviews mostly served to complement the documents, providing clarifications and explanations of various aspects evident in the documents (Table 1).

\section{Results of the two case studies}

The two cases represent two different ways of supporting SMEs in their efforts to improve their energy efficiency. We will briefly review the structure of both programmes, focusing on differences in terms of communication and knowledge production.

Case 1: an energy-efficiency programme controlled by the municipal administration

Case study 1 involves an energy efficient programme that ran from 2012 to 2015. Planning began in 2011, when the local government administration drew up a plan to cut the costs and reduce the carbon dioxide emissions of local SMEs by increasing their energy efficiency, mainly by modifying their support processes. Support processes include lighting, compressed air, ventilation, and other processes whose costs are usually summed as part of an installation's building envelope. The project involved 60 SMEs. Before SMEs joined the programme, representatives of the municipal administration (i.e. the project leader and local energy advisors) visited the SMEs to inform them about the programme and invite them to participate. The model to assist the SMEs entailed providing support in several steps, as shown in Fig. 1.

As part of the programme, local SMEs received a free "walk-through audit", i.e. a level-1 audit. A level-1 audit is characterized by a low level of detail, a short time spent at the company, and little money spent on the audit; it results in a less-detailed report making costeffective energy-efficiency improvement recommendations. The energy experts were publicly procured by the municipality, which wanted to support local energy

Table 1 Summary of methods and materials in the case studies

\begin{tabular}{|c|c|c|}
\hline Period & Case study 1 (2014-2016) & Case study 2 (2016-2018) \\
\hline Interviews & $\begin{array}{l}\text { Twenty-seven interviews with actors from SMEs (i.e. CEO, } \\
\text { owner, or energy manager) involved in the project; one } \\
\text { interview with the municipal environmental manager; one } \\
\text { interview with the municipal environmental strategist; one } \\
\text { interview with an energy expert in the project }\end{array}$ & $\begin{array}{l}\text { Four interviews with actors from SMEs involved in the } \\
\text { project; the project leader was interviewed five times; one } \\
\text { interview with each of the two energy experts involved }\end{array}$ \\
\hline Documents & $\begin{array}{l}\text { One municipal policy document; one Excel spreadsheet with } \\
\text { the results of the audits; three official reports for the } \\
\text { Swedish Energy Agency (SEA) }\end{array}$ & $\begin{array}{l}\text { Twenty-two final reports from the projects; one municipal } \\
\text { document; two official reports for the SEA }\end{array}$ \\
\hline Observations & $\begin{array}{l}\text { Participated in six meetings between the SEA and the } \\
\text { municipalities involved in the project; participated in two } \\
\text { meetings with municipal representatives and suppliers }\end{array}$ & None \\
\hline
\end{tabular}



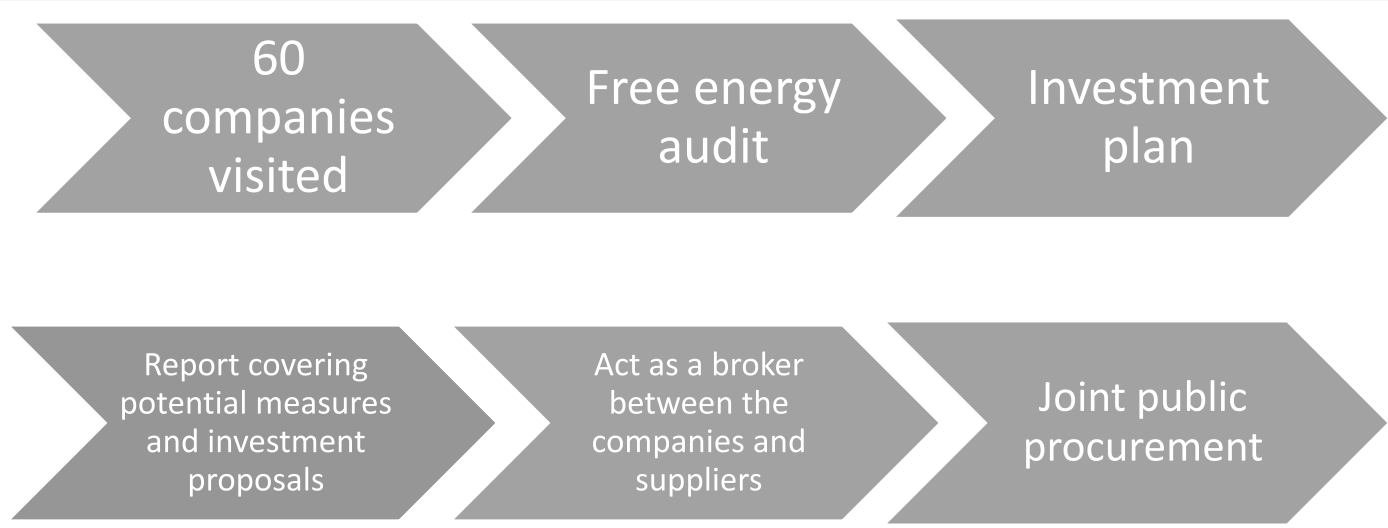

Fig. 1 Overview of the steps of the energy-efficiency programme

companies and SMEs (compare Palm and Backman 2017). Since 60 companies were promised energy audits and project funds were limited, each audit was a "budget audit" in which an energy consultant examined the factors that reflected the consultant's expertise. Several consultants were involved, and the process resulted in very heterogeneous audits, not necessarily related to, for example, the SMEs' goals. The "budget audits" also conflicted with the last step of the programme, which was to identify common needs of the participating SMEs in order to procure solutions en masse to gain economies of scale (data from the conducted energy audits).

These 60 audits resulted in a report used by the municipal project leader, who assumed the task of analysing how barriers to energy efficiency could be lowered for local SMEs. The SMEs themselves did not participate in the analysis, which was done for them and presented as an investment plan. The investment plan included costs for the suggested energy-efficiency measures, saving potentials, and profitability calculations for realizing the proposed measures. The municipality also invited suppliers to a meeting where they were given information from the energy audits. After this meeting, the idea was that these suppliers would provide a cost proposal to the SMEs on energy-efficiency technologies. This process was intended to lower information-related barriers for SMEs, such as the costs of obtaining energyefficiency information and technological solutions.

The focus of this energy-efficiency programme was to provide SMEs with information in the form of an energy audit report and an investment plan, in order to bridge the energy-efficiency gap that the municipal administration viewed as the root cause preventing SMEs from implementing energy-efficiency measures (Interviews: municipal project leader, environmental manager).
This energy-efficiency programme did not require the SMEs to contribute their own resources; the emphasis on the municipal side was on providing information through energy audits and, based on those, to come up with potential improvements. Every step of the programme was controlled by the municipal administration, from goal setting, choice of energy consultants, and how much the energy audit should cost, to identifying the factors the energy consultants should examine, the choice of suppliers to use, and the solutions to be presented. The SMEs were provided with explicit knowledge; they had no way to create knowledge or improve the tacit knowledge dimension.

The programme results showed that 2 years after the program ended, a few energy-efficiency measures had been undertaken by the participating SMEs. The original goal of a $20 \%$ reduction in energy consumption was only achieved by a few SMEs, according to the interview responses. The interviews revealed that in some cases, the energy audit reports were lost or misplaced when certain personnel left the companies (Interviews: SMEs 4, 12, and 17). One company did not implement any measures, and the respondent could not see how the suggested measures were relevant to the company: neither the energy audit nor the investment plan presented to the company "made sense" for the company (Interview: SME 9).

Most of the companies that implemented some measures had chosen "low-hanging fruit", such as replacing incandescent light bulbs with LED lights and turning off the lights at the end of the work cycle. One enterprise that had implemented several of the suggested energyefficiency measures said that the company did so because the measures aligned with their strategy and because they were consistent with customer demands 
(Interview: SME 8). In another example, a small retailer ordered a more thorough level-2 energy audit, since the manager saw great potential for the company to reduce costs and improve the profit margin (Interview: SME 5).

Also, the common procurement that was supposed to take place failed to materialize because it did not fit or interest more than a few of the participating SMEs. This result is in line with both Fleiter et al.'s (2011) and Schleich's (2009) findings that SME energy-efficiency measures are inherently heterogeneous and dependent on reinvestment cycles.

The SMEs generally found the project to be a rigid top-down process created by the municipality, in which the municipality controlled and ran most of the activities. This way of leading the project created anxiety and mistrust among the participating suppliers and SMEs.

Case 2: a network-based energy-efficiency programme

Case 2 involved another energy-efficiency programme that began in 2009, when the second studied municipality came together with the local business organization and the local industrial association to discuss how SMEs could improve their energy efficiency. The idea behind the project was to lower energy consumption to address the rising costs and decreased revenues of local SMEs. This programme was based on a model in which actors cooperate in a network to lower their energy use. The network in this case comprised various SMEs and energy experts, along with a municipal representative who acted as the project leader and moderator. This programme focused on SMEs' individual energyefficiency efforts, both during the project and after its completion (Interview: municipal project leader).

Before an enterprise joined the network, the project manager from the municipal administration visited the SME and talked with the management team to determine what expectations the team had and whether they were interested in working on an energy-saving project over a 10-month period. Interested companies paid EUR 1000 up front to join the project. The participating SMEs were offered training, tools, and support to help them address energy efficiency both together and individually. Each SME also agreed to document the actions taken, including realized and future measures, and to measure energy use at the start and end of the process. This became an important learning moment for the companies. A common efficiency target of decreasing idle energy use by 15-20\% was generally agreed on (Interview: municipal project leader).

The 10-month process began with the municipality inviting the interested companies to a 2-day course on the basics of performing an energy audit of their idle energy use. The course ended with the group collectively analysing one of the participating companies on site, with discussions led by an energy expert. In this way, the companies could learn from one another's mistakes and successes. An energy audit was then conducted at each participating company, with possible actions being identified by the SMEs themselves. This resulted in an action plan being drafted. The participating SMEs performed level-2 audits with the help of an energy expert who supported their decision-making process and helped with their energy efficiency work. A level-2 audit contains more information about single sites or processes than does a level-1 audit and includes an energy analysis with extensive measurements, detailed calculations on energy savings, and an evaluation of energy-efficiency improvement options.

Other important learning occasions were the monthly meetings, held for almost a year, where participating SMEs gathered for joint lectures, coaching, and "homework". Once the participants had completed an analysis and action plan, they continued to meet for half a day per month (Interview: municipal project leader). Every meeting had a theme that the SMEs had identified as valuable for their energy-efficiency work and that they had researched before the meeting, such as compressed air, ventilation, or lighting. Energy experts in these fields were invited to these meetings to talk with and advise the SMEs on how to address these issues. In addition, a week before each meeting, the invited energy expert would install measuring equipment at the SME where the meeting would be held, to measure the actual energy use and project the cost savings (Interview: energy expert). On each occasion, the meeting's agenda contained three items intended to improve the involved SMEs' understanding of energy efficiency: (1) exchange of experience and the opportunity to ask questions; (2) a discussion of real-time energy consumption; and (3) a walking tour of the enterprise hosting the meeting on that day. An important part of the project was for company representatives to visit various environments and experience different contexts in order to learn from other enterprises that had implemented relevant changes (Fig. 2). 

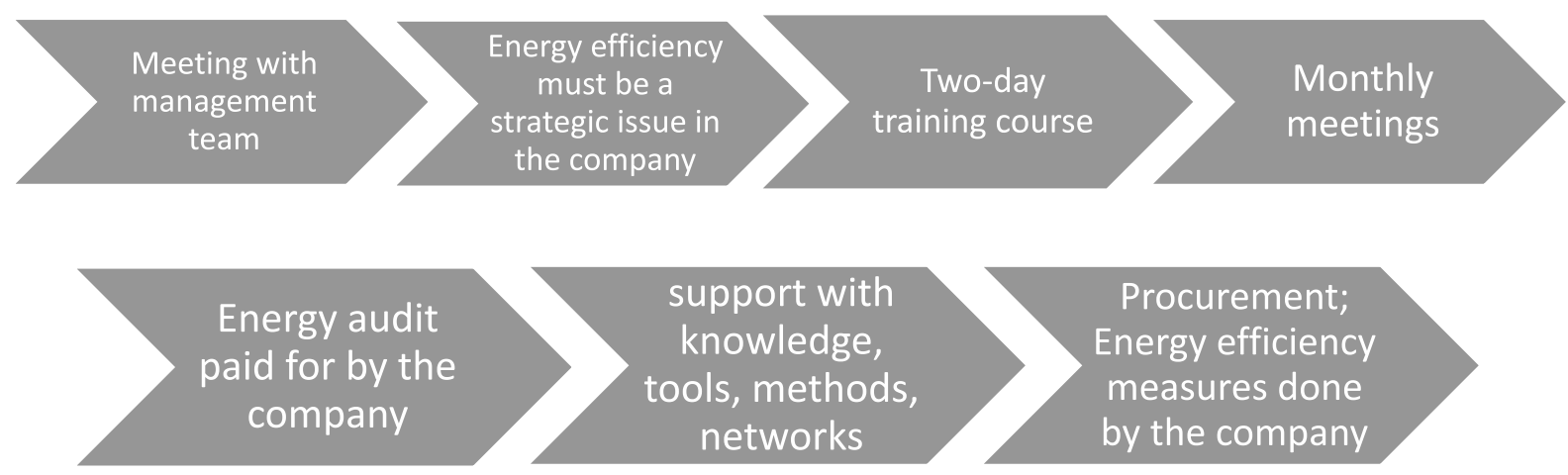

Fig. 2 The steps of the energy-efficiency programme in case 2

The common goal of decreasing idle energy use by 15-20\% was generally accomplished within a year after the project had ended; in some cases, a $30 \%$ or more decrease was achieved (data from SME final reports).

By working within a process like this, each SME could continue its own work, applying its new knowledge to its own unique conditions. In this process, information was distributed but also processed when the participants held discussions and dialogues based on their own experiences. These dialogues were always supported by the municipality's project management and by energy experts in different fields. This way of working with SMEs to improve their energy efficiency was similar to that of the energy-efficiency networks in Germany, which included medium-sized and large companies (Köwener et al. 2011; Köwener et al. 2014; Durand et al. 2018). The model also recalls the plando-check-act (PDCA) cycle (Deming 1986).

Table 2 Comparison of the results of the two case studies

\begin{tabular}{|c|c|c|}
\hline & Case 1 & Case 2 \\
\hline $\begin{array}{l}\text { Time period of the energy efficient } \\
\text { programme }\end{array}$ & 2012-2016 & 2009-2016 \\
\hline Number of companies involved & 60 & 22 \\
\hline Energy audit & $\begin{array}{l}\text { By consultants; free for the companies } \\
\text { (financed by municipality) }\end{array}$ & $\begin{array}{l}\text { Paid for by the companies; done by both } \\
\text { internal staff and consultants when needed }\end{array}$ \\
\hline Need for own resources & $\begin{array}{l}\text { No resources such as money, time, and } \\
\text { competence required from the involved } \\
\text { companies }\end{array}$ & $\begin{array}{l}\text { The companies contributed resources such } \\
\text { as money, time, and competence }\end{array}$ \\
\hline Network & $\begin{array}{l}\text { Face-to-face meetings between the municipal } \\
\text { project leader and the companies }\end{array}$ & $\begin{array}{l}\text { Monthly meetings including all companies } \\
\text { and the municipal project leader }\end{array}$ \\
\hline Site visits & $\begin{array}{l}\text { Procured energy consultants conducted } \\
\text { the energy audits }\end{array}$ & $\begin{array}{l}\text { The network meetings were held at individual } \\
\text { company premises; the project leader walked } \\
\text { through the site with company staff once, } \\
\text { or more often if needed }\end{array}$ \\
\hline Perspective & One-time effort & $\begin{array}{l}\text { Energy efficiency was to be embedded in the } \\
\text { organization and long-term commitment } \\
\text { was expected }\end{array}$ \\
\hline Communication & Written reports on results & $\begin{array}{l}\text { Monthly meetings and expert support when } \\
\text { the participating companies asked for it }\end{array}$ \\
\hline Learning & No in-house or peer-to-peer learning & $\begin{array}{l}\text { In-house learning was needed, and the programme } \\
\text { supported it with knowledge, tools, and methods, } \\
\text { but the companies did the work; peer-to-peer learning }\end{array}$ \\
\hline Procurement & Done by the project leader & Done by the company \\
\hline $\begin{array}{l}\text { Energy-efficiency improvement } \\
\text { reported by the companies }\end{array}$ & $\begin{array}{l}\text { Unclear for some SMEs; } 0-20 \% \text { for } \\
\text { those able to report }\end{array}$ & $15-30 \%$ \\
\hline
\end{tabular}


In this model, the focus was on helping local industries become "knowledgeable doers", implying a connection between reification and participation (Interview: municipal project leader). In this practice-based process, it was important for the companies to immerse themselves in the process and be active participants. The municipality was only there to support SMEs by providing funding, energy experts, and a project coordinator who generally moderated the meetings. In addition, the experts had different roles in cases 1 and 2. Instead of providing the SMEs with a long list of potential energy-efficiency measures and then telling them which measures to choose, the experts in case 2 helped the SMEs themselves identify what they needed (Interview: municipal project consultant). This energy-efficiency programme took a bottom-up approach in which SME needs came first. All studied companies implemented several of the proposed energy-efficiency measures, ranging from simply replacing incandescent light bulbs with LED lights and reducing staff use of energy, to more complex measures such as using district heating instead of electrical heating as a heat source (data from SME final reports).

An important aspect of this model was that the SMEs saw great relevance and added value in implementing the measures decided on. Only the measures that fitted each company were implemented, and the focus was on having each SME take ownership of its own process, albeit with external help. The municipality played a supporting role that focused on enabling the SMEs to work on their individual energy-efficiency processes, hiring a knowledgeable project leader with contacts among different energy experts who could help the participating SMEs.

\section{Conclusions}

The two cases differ fundamentally in how energy efficiency in industry was approached. Table 2 summarizes the results of the two case studies based on the results of the two programmes.

Municipalities are among several actors engaged in energy-efficiency work in SMEs; other actors such as consulting companies, trade associations, and applied research institutions also work in this area. In Germany, chambers of commerce and in Austria large utilities have also been important energy-efficiency actors (Durand et al. 2018). Municipalities can be important players in this context, as actors emphasizing sustainable transformation, though it is important that the time and resources spent by municipalities to support SMEs be wisely used.

The two cases here studied show two ambitious municipalities with explicit goals to support SMEs in improving their energy efficiency. When comparing the two programmes, case 2 was more successful when it came to improving energy efficiency (even if both programme contributed to improved energy efficiency). In case 1 it is however more difficult to relate improved energy efficiency back to the programme, compared to case 2. Several companies in case 1 meant that they would have done the measurement even without the participation in the programme.

The main difference between the programmes was how the SMEs were approached. In the first case, the SMEs involved in the project were provided with free energy audits and energy investment plans. The municipality wished to lower the thresholds to improving energy efficiency and had identified several barriers, such as lack of knowledge and capital. The idea was to provide the SMEs with enough information and free audits, which were themselves expected to induce the SMEs to implement energy-efficiency measures. In case 1 , the municipality steered the project based on its own goals, and the participating SMEs had little say regarding what goals should be fulfilled and how this should be done. The SMEs became passive recipients of information. The established network structure was never used, and the SMEs never came together as a network in peer-to-peer learning.

In case 2 , the municipality chose a different way to support SMEs in their energy-efficiency efforts. From the start, the focus was on having the involved SMEs become active participants in the project, so that they would provide input regarding their priorities and goals. The network structure was used to disseminate information, questions, and shared experiences between the SMEs. These are all aspects that have been highlighted as important when networking is used to achieve ambitious sustainability goals (Lazoroska and Palm 2019). The participating SMEs paid for the energy audit themselves and decided what measures to implement.

The importance of having a practice element in energy-efficiency programmes was supported by this study (cf. Wenger 1998). The results indicate that energy audits should be seen only as a starting point to identify the energy-efficiency potential of SMEs: the audits must 
then be complemented by energy-management practices in which the work is done by the SMEs themselves. This finding was supported by Chassein et al. (2018): when they asked energy managers in Germany about what influenced their energy-efficiency investments, most confirmed the importance of discussions at network meetings and that energy audits as such were not as important for their investments.

The energy-efficiency programme in case 1 applied a top-down approach, leading to a senderreceiver relationship that never contributed to any deep learning among the participating SMEs. The programme in case 1 was based on giving information and financial support to the SMEs, while the programme in case 2 supported the involved SMEs in actively working on energy efficiency in their own organizations, helping them develop the skills and knowledge needed in order to improve energy efficiency. The SMEs in case 2 improved their energy efficiency more than those in case 1 , and one reason for this seems to be that energy efficiency became embedded in the organizations, in line with Durand et al.'s (2018) findings.

When local authorities provide an energy audit and investment plan, as they did in case 1, this imposes their view of what measures should be taken and how energy efficiency should be improved. Such a one-size-fits-all approach does not work due to the heterogeneous technical structure of companies in different sectors in a region (compare, e.g. Fleiter et al. 2011; Schleich and Gruber 2008; Schleich 2009). In the more productive approach in case 2, the municipality supported the SMEs in a way that helped them meet their own energyefficiency goals by creating a network that facilitated knowledge creation with the help of various technical experts. The participating SMEs could then implement this knowledge and expert advice in their own operations. This approach has also been identified as successful in earlier studies by, for example, Köwener et al. (2011).

The barrier traditionally emphasized when discussing energy efficiency in SMEs has concerned knowledge, and it is indeed difficult for SMEs to automatically translate information into useable knowledge. According to community of practice and communication theory, the energy managers of the participating companies need to actively address energy efficiency in their day-to-day environments in order to negotiate, through practice, the results of energy audits and investment plans, leading to more realized energy-efficiency measures. Seeing stalled energy-efficiency improvement as resulting from communication barriers suggests that the best approach is that of case 2, incorporating long-term processes involving stakeholder meetings, commitment, active SME involvement, networking, and knowledge exchange and creation.

Funding information Open access funding provided by Lund University. This work is part of the project "Technology Procurement: Local Policy Means for Energy- Efficient Business", funded by the Swedish Energy Agency. We also want to thank two anonymous reviewers for their many constructive and valuable comments.

Open Access This article is licensed under a Creative Commons Attribution 4.0 International License, which permits use, sharing, adaptation, distribution and reproduction in any medium or format, as long as you give appropriate credit to the original author(s) and the source, provide a link to the Creative Commons licence, and indicate if changes were made. The images or other third party material in this article are included in the article's Creative Commons licence, unless indicated otherwise in a credit line to the material. If material is not included in the article's Creative Commons licence and your intended use is not permitted by statutory regulation or exceeds the permitted use, you will need to obtain permission directly from the copyright holder. To view a copy of this licence, visit http://creativecommons.org/licenses/by/4.0/.

\section{References}

Abdelaziz, E., Saidur, R., \& Mekhilef, S. (2011). A review on energy saving strategies in industrial sector. Renewable and Sustainble Energy Reviews, 15(1), 150-168.

Anderson, S. T., \& Newell, R. (2004). Information programs for technology adoption: The case of energy-efficiency audits. Resource and Energy Economics, 26(1), 27-50.

Arrow, K. J. (1971). He economic implications of learning by doing. Readings in the Theory of Growth (pp. 131-149). London: Palgrave Macmillan.

Backlund, S., Thollander, P., Palm, J., \& Ottosson, M. (2012). Extending the energy efficiency gap. Energy Policy, 51, 392396. https://doi.org/10.1016/j.enpol.2012.08.042.

Biggart, N. W., \& Lutzenhiser, L. (2007). Economic sociology and the social problem of energy inefficiency. American Behavioral Scientist, 50(8), 1070-1087. https://doi. org/10.1177/0002764207299355.

Bowen, G. A. (2009). Document analysis as a qualitative research method. Qualitative Research Journal, 9(2), 27-40.

Cabrera, E. F., \& Cabrera, A. (2005). Fostering knowledge sharing through people management practices. International Journal of Human Resource Management, 16(5), 720-735. https://doi.org/10.1080/09585190500083020.

Cagno, E., Worrell, E., Trianni, A., \& Pugliese, G. (2013). A novel approach for barriers to industrial energy efficiency (review). Renewable and Sustainable Energy Reviews, 19, 290-308. https://doi.org/10.1016/j.rser.2012.11.007. 
Ceglie, G., \& Dini, M. (1999). SME cluster and network development in developing countries: The experience of UNIDO. Vienna: UNIDO.

Chassein, E., Durand, A., Gerspacher, A., Jochem, E., \& Roser, A. (2018). Evaluation of regional learning energy efficiency networks - generation, audits, targeting, and network operation. IREES Working Paper No. 2 December 2018. Karlsruhe: IREES.

Choo, C. W., \& de Alvarenga Neto, R. C. D. (2010). Beyond the Ba: Managing enabling contexts in knowledge organizations. Journal of Knowledge Management, 14(4), 592-610. https://doi.org/10.1108/13673271011059545.

Chow, W. S., \& Chan, L. S. (2008). Social network, social trust and shared goals in organizational knowledge sharing. Information and Management, 45(7), 458-465. https://doi. org/10.1016/j.im.2008.06.007.

Coyne, I. T. (1997). Sampling in qualitative research. Purposeful and theoretical sampling; merging or clear boundaries? Journal of Advanced Nursing, 26(3), 623-630. https://doi. org/10.1046/j.1365-2648.1997.t01-25-00999.x.

Davenport, T. H., \& Prusak, L. (1998). Working knowledge: How organizations manage what they know. Harvard Business Press.

Decanio, S. J. (1998). The efficiency paradox: Bureaucratic and organizational barriers to profitable energy-saving investments. Energy Policy, 26(5), 441-454. https://doi. org/10.1016/S0301-4215(97)00152-3.

Deming, W. E. (1986). Out of the crisis. Cambridge, Mass: Massachusetts Institute of Technology, Center for Advanced Engineering Study.

Durand, A., Jochem, E., Chassein, E., Roser, A., Joest, S., \& Quezada, A. 2018-June (2018) 'Energy efficiency networks: Lessons learned from Germany' Eceee Industrial Summer Study Proceedings [conference paper]. Pp. 95-104. Available at: https://www.scopus.com/inward/record. uri?eid=2-s2.0-85049895500\&partnerID=40\&md5=98b09 e0f27da1580de9822e91a1ddd75.

Engelken, M., Römer, B., Drescher, M., Welpe, I. M., \& Picot, A. (2016). Comparing drivers, barriers, and opportunities of business models for renewable energies: A review. Renewable and Sustainable Energy Reviews, 60, 795-809.

Fleiter, T., Worrell, E., \& Eichhammer, W. (2011). Barriers to energy efficiency in industrial bottom-up energy demand models-A review. Renewable and Sustainable Energy Reviews, 15(6), 3099-3111.

Golove, W. H., \& Eto, J. H. (1996). Market barriers to energy efficiency: A critical reappraisal of the rationale for public policies to promote energy efficiency. CA (United States): Lawrence Berkeley Lab.

Gordić, D., Babić, M., Jovičić, N., Šušteršič, V., Končalović, D., \& Jelić, D. (2010). Development of energy management system-case study of Serbian car manufacturer. Energy Conversion and Management, 51(12), 2783-2790.

Hampton, S. (2019). Making sense of energy management practice: Reflections on providing low carbon support to three SMEs in the UK. Energy Efficiency, 12(6), 1473-1490. https://doi.org/10.1007/s12053-018-9750-5.

Henriques, J., \& Catarino, J. (2016). Motivating towards energy efficiency in small and medium enterprises. Journal of Cleaner Production, 139, 42-50.
Hildreth, P. M., \& Kimble, C. (2002). The duality of knowledge. Information Research, 8(1) https://www.scopus. com/inward/record.uri?eid=2-s2.0-2942567931 \&partnerID=40\&md5=ec34032dcff48265ece97eea $11 \mathrm{~d} 795$ a7.

IEA (2019). Tracking clean energy Progress. https://www.iea. org/tcep/?utm_campaign=IEA\%20newsletters\&utm source $=$ SendGrid\&utm_medium $=$ Email. Accessed $2 \overline{9}$ August 20192019.

Inkpen, A. C., \& Tsang, E. W. K. (2005). Social capital, networks, and knowledge transfer. The Academy of Management Review, 30(1), 146-165. https://doi.org/10.2307/20159100.

Jaffe, A. B., \& Stavins, R. N. (1994). The energy-efficiency gap what does it mean? Energy Policy, 22(10), 804-810. https://doi.org/10.1016/0301-4215(94)90138-4.

Jochem, E., \& Gruber, E. (2007). Local learning-networks on energy efficiency in industry-successful initiative in Germany. Applied Energy, 84(7), 806-816.

Kogut, B., \& Zander, U. (2003). Knowledge of the firm and the evolutionary theory of the multinational corporation. Journal of International Business Studies, 34(6), 516-529. https://doi.org/10.1057/palgrave.jibs.8400058.

Köwener, D., Jochem, E., Mai, M., \& Mielicke, U. (2011). 'Energy efficiency networks for companies-concept, achievements and prospects' ECEEE Summer Study Proceedings, Energy Efficiency First: The Foundation of a Low-Carbon Society (pp. 725-733). France: ECEEE.

Köwener, D., Nabitz, L., Mielicke, U., \& Idrissova, F. (2014) 'Learning energy efficiency networks for companies Saving potentials, realization and dissemination' [Conference Paper]. European Council for an Energy Efficient Economy, pp. 91-100. Available at: https://www. scopus.com/inward/record.uri?eid=2-s2.0-84978279288 \&partnerID $=40 \& \mathrm{md} 5=8 \mathrm{~d} 89 \mathrm{de} 0835 \mathrm{adb} 1 \mathrm{e} 6 \mathrm{bd} 0 \mathrm{~b} 8 \mathrm{a} 5 \mathrm{f} 9856$ e81d.

Kvale, S., \& Brinkmann, S. (2009). InterViews: Learning the craft of qualitative research interviewing. Los Angeles: Sage Publications.

Labanca, N., \& Bertoldi, P. (2018). Beyond energy efficiency and individual behaviours: Policy insights from social practice theories. Energy Policy, 115, 494-502.

Lave, J., \& Wenger, E. (1991). Situated learning : Legitimate peripheral participation. Cambridge: Cambridge Univ. Press.

Lazoroska, D., \& Palm, J. (2019). Dialogue with property owners and property developers as a tool for sustainable transformation: A literature review. Journal of Cleaner Production, 233, 328-339.

Light, J. (1989). Toward a definition of communicative competence for individuals using augmentative and alternative communication systems. Augmentative and Alternative Communication, 5(2), 137-144. https://doi.org/10.1080 $/ 07434618912331275126$.

Lorenzen, M. (2001). Ties, trust, and trade. International Studies of Management and Organization, 31(4), 14-34. https://doi. org/10.1080/00208825.2001.11656825.

Matusik, S. F., \& Charles, W. L. H. (1998). The utilization of contingent work, knowledge creation, and competitive advantage. The Academy of Management Review, 23(4), 680697. https://doi.org/10.2307/259057. 
Mayer, R. E. (1992). Cognition and instruction: Their historic meeting within educational psychology. Journal of Educational Psychology, 84(4), 405.

Meredith, J. (1998). Building operations management theory through case and field research. Journal of Operations Management, 16(4), 441-454 https://www.scopus. $\mathrm{com} /$ inward/record.uri?eid=2-s2.0-0032119946 \&partnerID $=40 \& \mathrm{md} 5=8986 \mathrm{e} 208 \mathrm{e} 4236 \mathrm{f} 760 \mathrm{f} 7087 \mathrm{bee} 5 \mathrm{f} 7$ cf 25 .

Nahapiet, J., \& Ghoshal, S. (1998). Social capital, intellectual capital, and the organizational advantage. Academy of Management Review, 23(2), 242-266. https://doi. org/10.5465/AMR.1998.533225.

Nonaka, I. (1994). A dynamic theory of organizational knowledge creation. Organization Science, 5(1), 14-37. https://doi. org/10.1287/orsc.5.1.14.

Nonaka, I., \& Takeuchi, H. (1995). The knowledge-creating company : How Japanese companies create the dynamics of innovation. New York: Oxford University Press.

Nonaka, I., \& von Krogh, G. (2009). Tacit knowledge and knowledge conversion: Controversy and advancement in organizational knowledge creation theory. Organization Science, 20(3), 635-652. https://doi.org/10.1287/orsc.1080.0412.

Noorderhaven, N., \& Harzing, A.-W. (2009). Knowledge-sharing and social interaction within MNEs. Journal of International Business Studies, 40(5), 719-741.

Palm, J. (2009). Placing barriers to industrial energy efficiency in a social context: A discussion of lifestyle categorisation. Energy Efficiency, 2(3), 263-270. https://doi.org/10.1007 /s12053-009-9042-1.

Palm, J., \& Backman, F. (2017). Policy network creation as a driver of energy-efficient industry. International Journal of Energy Sector Management, 11(1), 143-157. https://doi. org/10.1108/IJESM-10-2015-0004.

Palm, J., \& Thollander, P. (2020). Reframing energy efficiency in industry - A discussion of definitions. In M. Lopes, C. Henggeler, \& K. B. Janda (Eds.), Energy and Behaviour: challenges of a low-carbon future. London: Academic press.

Patton, M. Q. (2015). Qualitative research \& evaluation methods : Integrating theory and practice. Thousand Oaks, California: SAGE Publications, Inc.

Pinch, S., Henry, N., Jenkins, M., \& Tallman, S. (2003). From 'industrial districts' to 'knowledge clusters': A model of knowledge dissemination and competitive advantage in industrial agglomerations. Journal of Economic Geography, 3(4), 373-388. https://doi.org/10.1093/jeg/lbg019.

Polanyi, M. (1983). The tacit dimension. Gloucester, Mass: Peter Smith.

Probst, G., \& Borzillo, S. (2008). Why communities of practice succeed and why they fail. European Management Journal, 26(5), 335-347. https://doi.org/10.1016/j.emj.2008.05.003.

Rohdin, P., Thollander, P., \& Solding, P. (2007). Barriers to and drivers for energy efficiency in the Swedish foundry industry. Energy Policy, 35(1), 672-677.

Rubin, H. J., \& Rubin, I. S. (2012). Qualitative interviewing: The art of hearing data. Thousand Oaks, Calif: SAGE.
Sanstad, A. H., \& Howarth, R. B. (1994). 'Normal'markets, market imperfections and energy efficiency. Energy Policy, 22(10), 811-818.

Schleich, J. (2009). Barriers to energy efficiency: A comparison across the German commercial and services sector. Ecological Economics, 68(7), 2150-2159. https://doi. org/10.1016/j.ecolecon.2009.02.008.

Schleich, J., \& Gruber, E. (2008). Beyond case studies: Barriers to energy efficiency in commerce and the services sector. Energy Economics, 30(2), 449-464. https://doi.org/10.1016 j.eneco.2006.08.004.

Sorrell, S. (2004). The economics of energy efficiency: Barriers to cost-effective investment. Cheltenham: Edward Elgar.

Star, S. L., \& Griesemer, J. R. (1989). Institutional ecology, 'translations' and boundary objects: Amateurs and professionals in Berkeley's Museum of Vertebrate Zoology, 190739. Social Studies of Science, 19(3), 387-420. https://doi. org/10.1177/030631289019003001.

Terzieva, M. (2014). Project knowledge management: How organizations learn from experience. Procedia Technology, 16, 1086-1095. https://doi.org/10.1016/j.protcy.2014.10.123.

Thollander, P., \& Palm, J. (2013). Improving energy efficiency in industrial energy systems : An interdisciplinary perspective on barriers, energy audits, energy management, policies, and programs. London: Springer.

Thollander, P., \& Palm, J. (2015). Industrial energy management decision making for improved energy efficiency-strategic system perspectives and situated action in combination. Energies, 8(6), 5694-5703. https://doi.org/10.3390 len8065694.

Thollander, P., Palm, J., \& Rohdin, P. (2010). Categorizing barriers to energy efficiency-an interdisciplinary perspective. In J. Palm (Ed.), Energy efficiency (pp. 49-62). Croatia: INTECH Open Access Publisher.

Trianni, A., \& Cagno, E. (2012). Dealing with barriers to energy efficiency and SMEs: Some empirical evidences. Energy, 37(1), 494-504. Doi:https://doi.org/10.1016/j. energy.2011.11.005.

Trianni, A., Cagno, E., \& Farné, S. (2016). Barriers, drivers and decision-making process for industrial energy efficiency: A broad study among manufacturing small and medium-sized enterprises. Applied Energy, 162, 1537-1551.

Urbaniec, M., \& Gerstlberger, W. (2011). Innovation in environment-oriented networks: Influence factors from case study and survey research. Management of Environmental Quality: An International Journal, 22(6), 686-704.

Väisänen, H., Christensen, W., Despretz, H., Aamodt Espegren, K., Gaspar, K., Lytras, K., et al. (2002) 'Guidebook for energy audit Programme developers.'.

Wenger, E. (1998). Communities of practice : Learning, meaning, and identity. Cambridge: Cambridge University Press.

Publisher's note Springer Nature remains neutral with regard to jurisdictional claims in published maps and institutional affiliations. 